Article

\title{
Comparison of Three Real-Time PCR Assays for the Detection of Cyclospora cayetanensis in Stool Samples Targeting the 18S rRNA Gene and the $h s p 70$ Gene
}

\author{
Felix Weinreich ${ }^{1}\left(\mathbb{D}\right.$, Andreas Hahn ${ }^{2} \mathbb{D}$, Kirsten Alexandra Eberhardt ${ }^{3} \mathbb{D}$, Torsten Feldt ${ }^{4}$, Fred Stephen Sarfo ${ }^{5}$, \\ Veronica Di Cristanziano ${ }^{6} \mathbb{D}$, Hagen Frickmann ${ }^{1,2,+} \mathbb{D}$ and Ulrike Loderstädt ${ }^{7, *,+}$
}

Citation: Weinreich, F.; Hahn, A.; Eberhardt, K.A.; Feldt, T.; Sarfo, F.S. Di Cristanziano, V.; Frickmann, H.; Loderstädt, U. Comparison of Three Real-Time PCR Assays for the Detection of Cyclospora cayetanensis in Stool Samples Targeting the $18 \mathrm{~S}$ rRNA Gene and the $h s p 70$ Gene. Pathogens 2022, 11, 165. https:// doi.org/10.3390/pathogens11020165

Academic Editors: Fabio Tramuto and Olivier Sparagano

Received: 23 December 2021

Accepted: 25 January 2022

Published: 26 January 2022

Publisher's Note: MDPI stays neutral with regard to jurisdictional claims in published maps and institutional affiliations.

Copyright: (C) 2022 by the authors. Licensee MDPI, Basel, Switzerland. This article is an open access article distributed under the terms and conditions of the Creative Commons Attribution (CC BY) license (https:// creativecommons.org/licenses/by/ $4.0 /)$.
1 Department of Microbiology and Hospital Hygiene, Bundeswehr Hospital Hamburg, 20359 Hamburg, Germany; felixweinreich@bundeswehr.org (F.W.); frickmann@bnitm.de (H.F.)

2 Department of Medical Microbiology, Virology and Hygiene, University Medicine Rostock, 18057 Rostock, Germany; andreas.hahn@uni-rostock.de

3 Department of Tropical Medicine, Bernhard Nocht Institute for Tropical Medicine \& I. Department of Medicine, University Medical Center Hamburg-Eppendorf, 20359 Hamburg, Germany; k.eberhardt@bnitm.de

4 Department of Gastroenterology, Hepatology and Infectious Diseases, University Medical Center Düsseldorf, 40225 Düsseldorf, Germany; torsten.feldt@med.uni-duesseldorf.de

5 Department of Medicine, Kwame Nkrumah University of Science and Technology, Kumasi 00233, Ghana; fsarfo.chs@knust.edu.gh

6 Institute of Virology, Faculty of Medicine and University Hospital of Cologne, University of Cologne, 50935 Cologne, Germany; veronica.di-cristanziano@uk-koeln.de

7 Department of Hospital Hygiene \& Infectious Diseases, University Medicine Göttingen, 37075 Göttingen, Germany

* Correspondence: ulrike.loderstaedt1@med.uni-goettingen.de; Tel.: +49-551-3965709

+ These authors contributed equally to this work.

\begin{abstract}
Diagnostic real-time PCR for the detection of Cyclospora cayetanensis in human stool samples has been applied for two decades. However, recent comparative assessments between in-house and commercial assays suggested room for improvement regarding the agreement of positive signals of the applied real-time PCRs. In order to assess the effect of the choice of the target sequence, 3 inhouse real time PCR assays targeting the 18S rRNA gene $(n=2$, one of them later referred to as SSU rRNA gene assay to avoid confusion) and the $h s p 70$ gene of $C$. cayetanensis were compared in a head-to-head comparison with 905 samples with high pretest probability for $C$. cayetanensis infections from Ghanaian HIV patients in a test comparison without a reference standard. Only slight agreement kappa of 0.095 was observed. In the assays targeting the SSU rRNA gene, the 18S rRNA gene, and $h s p 70$, positive signals were recorded in 63, 45, and 0 instances, respectively, with latent class analysis-based estimation of sensitivity of $32.2 \%, 23.3 \%, 0 \%$ as well as of specificity of $99.7 \%$, $99.9 \%$ and $100 \%$, respectively. High cycle threshold values with an average of about 35 indicated low quantities of target DNA in the samples with similar Ct values in concordantly and discordantly positive samples. In conclusion, the study suggested target-gene-specific differences in the diagnostic accuracy of real-time PCR-based diagnosis of C. cayetanensis as well as an ongoing need for further standardization of this diagnostic approach.
\end{abstract}

Keywords: Cyclospora cayetanensis; stool; real-time PCR; diagnosis; test comparison; evaluation; validation; latent class analysis; without reference standard

\section{Introduction}

Cyclospora cayetanensis are coccidian parasites causing enteric disease in human patients following fecal-oral transmission [1,2] with an obligatory environmental sporulation step in water or soil [1]. Consequently, cyclosporiasis is correlated both with environmental exposition [3,4] and with increased occurrence in the rainy season $[5,6]$. Clinically 
apparent disease resulting from infections of the upper small intestinal tract is usually self-limiting in the immunocompetent host [7], while complications such as chronic diarrhea, villous atrophy and crypt hyperplasia have been described from immunodeficient patients $[1,2,5,8,9]$.

As typical for fecal-orally transmitted pathogens, prevalence is particularly high in resource-limited settings where established hygiene regimens leave room for improvement as well as in travelers returning from such settings [1,10-17].

While the diagnosis of C. cayetanensis has traditionally been based on microscopy [2], usually following acid-fast staining or alternative approaches to increase visibility within stool specimens as well as enrichment steps to increase sensitivity [2,18-21], both in-house and commercial molecular diagnostic assays have been described in the meantime [5,22-26]. In recent comparisons of commercial and in-house real-time PCR assays, however, there was a surprisingly low agreement between different molecular $C$. cayetanensis-specific assays $[25,26]$. Interestingly, this finding was accompanied by a generally higher sensitivity of real-time PCR compared to microscopy $[25,27]$. The reasons for the observed mismatching between the recorded positive results in the commercial and the in-house real-time PCR assays $[25,26]$ remained unclear. As the applied oligonucleotides are usually not published for commercial molecular diagnostic assays, it could not be checked whether or not different target sequences of the real-time PCR assays could be the reason for the observed discrepancy $[25,26]$. As the choice of the target sequence is of critical importance for the reliability of a diagnostic real-time PCR assay [28,29], it is likely that different target sequences as previously reported for $C$. cayetanensis $[25,26,30-33]$ may have played a role.

In order to further investigate a likely target sequence dependence of inconsistent C. cayetanensis real-time PCR results, 3 different real-time PCR assays targeting the $18 \mathrm{~S}$ ribosomal RNA (18S rRNA) gene ( $n=2$, one of them later referred to as the small subunit ribosomal RNA (SSU rRNA) gene assay to make the discrimination easier) and the heat shock protein 70 ( $h s p 70)$ gene $[25,26,30-32]$ were compared in a head-to-head comparison without a reference standard by applying a latent class analysis-(LCA-) based assessment [28,34]. The target genes were chosen for the comparisons as they are frequently applied in diagnostic C. cayetanensis assays [22-27,30-32], so their comparative assessment should be of interest for both test developers and clinical microbiologists interpreting the diagnostic results. To ensure a sufficient pre-test probability associated with enough positive test results for a meaningful investigation, residual sample materials from study participants from resource-limited settings with increased risk of $C$. cayetanensis infections $[11,12,14-16]$ were chosen for the test comparison without a reference standard.

\section{Materials and Methods}

\subsection{Residual Sample Collection and Nucleic Acid Extraction}

A total of 905 nucleic acid extractions from stool samples collected from Ghanaian HIV patients $(n=905)[35,36]$ were used for this study. The samples had already been successfully applied for comparative evaluations of real-time PCR assays targeting either microsporidia [37] or other coccidian parasites [38,39], so a high likelihood of a relevant proportion of samples positive for various parasites could be assumed for the assessment. Assessments for $C$. cayetanensis had not been performed so far with these samples prior to this study.

\subsection{Applied In-House Real-Time PCRs}

In a head-to-head comparison without a reference standard, three real-time PCR assays targeting the SSU rRNA gene, the 18S rRNA gene and the $h s p 70$ gene (Table 1) were run on RotorGene Q cyclers (Qiagen, Hilden, Germany) or magnetic induction cyclers (MIC, Bio Molecular Systems Ltd., London, UK) as described [30-32] with minor modifications. All protocols had been established on both cycler models in the same laboratory in parallel and showed comparable performance characteristics on both. In detail, the Qiagen HotStar Taq master mix (Qiagen, Hilden, Germany) at the standard concentration as recommended by 
the manufacturer with a final $\mathrm{Mg}^{2+}$ concentration (Qiagen, Hilden, Germany) of $5 \mathrm{mM}$ and $0.05 \mathrm{ng} / \mathrm{mL}$ bovine serum albumin (BSA; Carl Roth, Karlsruhe, Germany) was applied in $20 \mu \mathrm{L}$ total reaction volumes containing $2 \mu \mathrm{L}$ sample eluate each as decided in the course of the in-house optimization of the protocols. For the target genes SSU rRNA, 18S rRNA and hsp 70 , forward primer concentrations were $1 \mathrm{pmol} / \mu \mathrm{L}, 0.5 \mathrm{pmol} / \mu \mathrm{L}$ and $1.3 \mathrm{pmol} / \mu \mathrm{L}$, reverse primer concentrations $2.0 \mathrm{pmol} / \mu \mathrm{L}, 0.5 \mathrm{pmol} / \mu \mathrm{L}$ and $1.3 \mathrm{pmol} / \mu \mathrm{L}$, respectively, and probe concentrations $2.0 \mathrm{pmol} / \mu \mathrm{L}, 0.5 \mathrm{pmol} / \mu \mathrm{L}$ and $1.3 \mathrm{pmol} / \mu \mathrm{L}$, respectively. The run conditions comprised an initial activation step at $95^{\circ} \mathrm{C}$ for $15 \mathrm{~min}$ followed by 55 cycles comprising denaturation at $95^{\circ} \mathrm{C}$ for $15 \mathrm{~s}$, annealing for $30 \mathrm{~s}$ starting at $67^{\circ} \mathrm{C}$ with a touchdown of $0.5^{\circ} \mathrm{C}$ per cycle for 13 cycles, and amplification at $72{ }^{\circ} \mathrm{C}$ for $30 \mathrm{~s}$ each with final cooling down to $40^{\circ} \mathrm{C}$ for $20 \mathrm{~s}$. PCR inhibition was controlled with an inhibition control real-time PCR targeting a phocid herpes virus (PhHV) DNA sequence was described elsewhere [40]. Inhibited samples with positive $C$. cayetanensis-specific signals were excluded from the diagnostic accuracy assessment. All PCRs were run with a plasmid-based positive control (see Table A1 in Appendix A) and a PCR water-based negative control sample. As assessed with a dilution series of the positive control plasmid and calculated with the software SciencePrimer.com (http:/ / scienceprimer.com/copy-number-calculator-for-realtime-pcr, last accessed on 23 December 2021), the limits of detection for the assays were less than 10 copies per $\mu \mathrm{L}$ eluate for the SSU rRNA and $18 \mathrm{~S}$ rRNA PCRs. For the $h s p 70$ gene, a slightly higher limit of detection of 31 copies per $\mu \mathrm{L}$ was calculated.

Table 1. Applied oligonucleotide sequences of the compared C. cayetanensis-specific real-time PCR assays [30-32].

\begin{tabular}{|c|c|c|c|c|c|}
\hline $\begin{array}{c}\text { Forward Primer } \\
\text { Name }\end{array}$ & $\begin{array}{l}\text { Forward Primer } \\
\text { Sequence }\end{array}$ & $\begin{array}{c}\text { Reverse Primer } \\
\text { Name }\end{array}$ & $\begin{array}{l}\text { Reverse Primer } \\
\text { Sequence }\end{array}$ & Probe Name & Probe Sequence \\
\hline \multicolumn{6}{|c|}{ SSU rRNA gene PCR according to Verweij et al. [30] } \\
\hline Cyclo250F & $\begin{array}{l}\text { 5'-TAGTAACCGAA- } \\
\text { CGGATCGCATT-3' }\end{array}$ & Cyclo350R & $\begin{array}{l}\text { 5'-AATGCCACGG- } \\
\text { TAGGCCAATA-3' }\end{array}$ & Cyclo281T & $\begin{array}{c}\text { 5'-CCGGCGA- } \\
\text { TAGATCATTCAAG- } \\
\text { TTTCTGACC-3' }\end{array}$ \\
\hline \multicolumn{6}{|c|}{ 18S rRNA gene PCR according to Varma et al. [31] } \\
\hline VarmaF & $\begin{array}{c}\text { 5'-TGAACTCATT- } \\
\text { GGACTGACCAGC-3' }\end{array}$ & VarmaR & $\begin{array}{l}\text { 5'-ACTTTTGCATCC- }^{\prime} \text { TTTAGAGGGCT-3' } \\
\text { TTA }\end{array}$ & VarmaP & $\begin{array}{l}\text { 5'-TTCGCGGAGCT- } \\
\text { GGTCGGAAAGTTG-3' }\end{array}$ \\
\hline \multicolumn{6}{|c|}{ hsp70 gene PCR according to Shields et al. [32] } \\
\hline HMPr36 & $\begin{array}{l}\text { 5'-GGGTAAGC- } \\
\text { CACTTATTGA-3' }\end{array}$ & HMPr40 & $\begin{array}{l}\text { 5'-GCCTCCTTA- }^{\prime} \text { ACTTCTTTG-3 }{ }^{\prime}\end{array}$ & HMPro53 & $\begin{array}{c}\text { 5'-CCTTCATCT- } \\
\text { TCACCAGCACCA-3' }\end{array}$ \\
\hline
\end{tabular}

\subsection{Statistical Assessment}

Latent class analysis (LCA) [28,34] was applied for the test comparison without a reference standard in order to calculate sensitivity and specificity of the applied test assays as well as for an accuracy-adjusted prevalence estimation. LCA is a variant of structural equation models which aims at estimating latent non-observed variables as the actual disease status over observed variables, e.g., the results of diagnostic test assays. Concordance according to Fleiss' kappa was calculated and interpreted as described elsewhere [41]. In more detail, Fleiss' kappa indicated the agreement between the qualitative results of the real-time PCRs with the strata poor (below 0.00), slight $(0.00-0.20)$, fair $(0.21-0.40)$, moderate $(0.41-0.60)$, substantial $(0.61-0.80)$, and almost perfect $(0.81-1.00)$ as defined previously [41]. The cycle threshold $(\mathrm{Ct})$ values of the real-time PCRs were descriptively compared. The statistical assessments were performed using the software Stata/IC 15.1 for Mac 64-bit Intel (College Station, TX, USA).

\section{Results}

From the 905 assessed samples of Ghanaian HIV patients, 33 were excluded from the further diagnostic accuracy estimations due to recorded sample inhibition as indicated by the PhHV-specific inhibition control PCR. Of note, those excluded samples comprised 
1 sample positive in the SSU rRNA gene PCR and another sample positive in the $18 \mathrm{~S}$ rRNA gene PCR.

In the non-inhibited samples, the recorded cycle threshold $(\mathrm{Ct})$ values for the PhHVDNA-based inhibition control target showed a mean value ( \pm standard deviation $S D)$ of $33.9( \pm 3.0)$ and a median (minimum, maximum) of $33.3(23.1,48.0)$. In total, recorded detections of the targeted $C$. cayetanensis sequences among the 872 included samples succeeded in $62(7.1 \%)$ cases for the SSU rRNA gene, in $44(5.1 \%)$ cases for the $18 \mathrm{~S}$ rRNA gene, and in $0(0 \%)$ cases for the $h s p 70$ gene. Thereby, 14 samples were indicated as positive by both SSU rRNA gene PCR and $18 \mathrm{~S}$ rRNA gene PCR. LCA-based diagnostic accuracyadjusted prevalence estimation resulted in a prevalence of $21.4 \%(14.0 \%, 31.4 \%)$ in the assessed population of Ghanaian HIV patients.

Agreement kappa over the 3 different compared assays was slight according to the interpretation standards as suggested by Landis and Koch [41]. Sensitivity as calculated by applying LCA was $32.2 \%$ for the SSU rRNA gene PCR, 23.3\% for the 18 S rRNA gene PCR and $0.0 \%$ for the $h s p 70$ PCR. The specificity values were $99.7 \%$ for the SSU rRNA gene PCR, $99.9 \%$ for the $18 \mathrm{~S}$ rRNA gene PCR and $100 \%$ for the $h s p 70$ PCR as estimated by LCA. Due to the low agreement, no 0.95 confidence intervals could be calculated for these estimated specificity values, implying that their 0.95 confidence intervals could theoretically cover the full spectrum from $0 \%$ to $100 \%$. Details including estimable confidence intervals are shown in Table 2, a cross table indicating the matches and mismatches among the 872 included samples is presented in Table 3.

Table 2. Agreement kappa between the compared real-time PCR assays as well as sensitivity, specificity and accuracy-adjusted prevalence as calculated with latent class analysis (LCA). Samples showing inhibition in the inhibition control PCR were excluded from the assessment, resulting in a total of 872 included samples.

\begin{tabular}{cccccc}
\hline Assay & $n$ & Positives (\%) & $\begin{array}{c}\text { Sensitivity } \\
\mathbf{( 0 . 9 5 ~ C I )}\end{array}$ & $\begin{array}{c}\text { Specificity } \\
\mathbf{( 0 . 9 5 ~ C I )}\end{array}$ & $\begin{array}{c}\text { Kappa } \\
\mathbf{( 0 . 9 5} \text { CI) }\end{array}$ \\
\hline $\begin{array}{c}\text { SSU rRNA gene PCR according to } \\
\text { Verweij et al. [30] }\end{array}$ & 872 & $62(7.11)$ & $\begin{array}{c}0.322 \\
(0.200,0.473)\end{array}$ & 0.997 (n.e.) \\
\hline $\begin{array}{c}\text { 18S rRNA gene PCR according to } \\
\text { Varma et al. [31] }\end{array}$ & 872 & $44(5.05)$ & $\begin{array}{c}0.233 \\
(0.142,0.357)\end{array}$ & 0.999 (n.e.) & 1 (n.e.) \\
\hline $\begin{array}{c}\text { hsp70 PCR according to } \\
\text { Shields et al. [32] }\end{array}$ & 872 & 0 & $0.045,0.164)$ & \\
\hline $\begin{array}{c}\text { Prevalence } \\
(0.95 \mathrm{CI})\end{array}$ & & $0.214(0.140,0.314)$ & \\
\hline
\end{tabular}

$0.95 \mathrm{CI}=95 \%$-confidence intervals. $n=$ numbers. n.e. $=$ non-estimable.

Table 3. Cross-table detailing matches and mismatches between the SSU rRNA gene and the 18S rRNA gene PCR assays. Samples showing inhibition in the inhibition control PCR were excluded from the assessment, resulting in a total of 872 included samples. The $h s p 70$ PCR was not included in the cross-table, as it did not show positive results at all and so, it was just discordant with 62 positive signals in the SSU rRNA gene PCR and with 44 positive signals in the $18 \mathrm{~S}$ rRNA gene PCR.

\begin{tabular}{cccc}
\hline & \multicolumn{3}{c}{ SSU rRNA Gene PCR according to Verweij et al. [30] } \\
\hline & & Negative & Positive \\
\hline 18S rRNA gene PCR according & negative & 780 & 48 \\
to Varma et al. [31] & positive & 30 & 14 \\
\hline
\end{tabular}

Descriptive assessment of the recorded cycle threshold $(\mathrm{Ct})$ values indicated predominantly high values of 35 cycles and more. Further, the differences between the SSU rRNA gene PCR and the 18S rRNA gene PCR were negligible with considerably overlapping confidence intervals. Focusing on the 14 samples positive in SSU rRNA gene PCR and $18 \mathrm{~S}$ 
rRNA gene PCR, of note, the average and median $\mathrm{Ct}$ values were in the same range. Details are provided in Table 4.

Table 4. Recorded cycle threshold $(\mathrm{Ct})$ values of the real-time PCR assays. All positive test results among the 905 assessed samples were included, also the 2 samples with positive PCR signals which had been excluded from diagnostic accuracy assessment due to sample inhibition as stated above.

\begin{tabular}{lccc}
\hline Assay & $n$ & Mean (SD) & Median (Min, Max) \\
\hline SSU rRNA gene PCR according to Verweij et al. [30] & 63 & $34.4( \pm 4.39)$ & $35.04(23.78,43.77)$ \\
\hline $\begin{array}{l}\text { SSU rRNA gene PCR according to Verweij et al. [30] } \\
\text { for samples also positive in the 18S rRNA gene PCR }\end{array}$ & 14 & $35.43( \pm 4.55)$ & $34.92(23.78,42.67)$ \\
\hline 18S rRNA gene PCR according to Varma et al. [31] & 45 & $36.92( \pm 3.26)$ & $36.53(30.89,46.90)$ \\
\hline $\begin{array}{l}\text { 18S rRNA gene PCR according to Varma et al. [31] for } \\
\text { samples also positive in the SSU rRNA gene PCR }\end{array}$ & 14 & $36.40( \pm 3.19)$ & $35.87(33.60,46.90)$ \\
\hline $\begin{array}{l}\text { hsp70 PCR according to Shields et al. [32] } \\
n=\text { numbers. SD = standard deviation. Min = minimum. Max = maximum. n.a. = not applicable. }\end{array}$
\end{tabular}

\section{Discussion}

The study was performed to further investigate the recently observed phenomenon of considerable discordance of positive signals in in-house and commercial real-time PCR assays targeting $C$. cayetanensis $[25,26]$. In detail, slight agreement [41] with a kappa value of $0.184(-0.064,0.431)$ had been recorded in a comparison of the same in-house SSU rRNA gene PCR as applied in the present study and the LightMix Modular Cyclospora assay (TIB MOLBIOL, Berlin, Germany) targeting the $18 \mathrm{~S}$ rRNA gene of Cyclospora cayetanensis in a test comparison without a reference standard with residual stool sample materials with a high pretest probability but without microscopic pre-characterization [26]. In another similar study comparing this in-house SSU rRNA gene assay with both microscopy and the Cyclospora cayetanensis-specific real-time PCR within the commercial Allplex GI panel 4 (SeeGene, Seoul, Korea), for which the molecular target is not publicly available, with residual stool sample materials from tropical travel returnees, only moderate agreement with a kappa value of $0.432(0.309,0.548)$ had been observed as well [25]. Low total numbers of $C$. cayetanensis detections in both previous studies made the interpretation of these findings challenging. However, the repeated observation of a likely agreement problem triggered the present study on a potential influence of commonly applied target genes on the diagnostic accuracy of the assays. Again, the study was conducted as a test comparison without a reference standard with residual samples with a high pre-test probability but without microscopic characterization, which were available from a previous epidemiological investigation with HIV-positive Ghanaian patients [35,36].

The observed slight agreement between SSU rRNA gene-specific, 18S rRNA genespecific and $h s p 70$-specific real-time PCR with a kappa of $0.095(0.045,0.164)$ in the present study is within the confidence interval of the kappa of $0.184(-0.064,0.431)$ as recorded in the previous comparison of in-house SSU rRNA gene PCR and commercial 18S rRNA gene PCR [26]. Of note, $h s p 70$ PCR did not show positive signals at all and so, the agreement of positive signals within the present study resulted from concordantly positive signals between the SSU rRNA gene PCR and the 18S rRNA gene PCR alone. This additional finding confirms the suspicion arising from the previous assessments $[25,26]$ that the discordance between positive $C$. cayetanensis real-time PCR results is likely to be relevantly influenced by the choice of the target sequence among the commonly used real-time PCR targets for the diagnostic detection of $C$. cayetanensis [5,22-27,30-33]. This finding may seem trivial at first glance but is nevertheless in contrast to the promising findings of previous evaluation studies for the chosen C. cayetanensis-specific target genes [30-32], according to which higher diagnostic reliability and thus better agreement should have been expected.

In addition, the details as observed in this study deserve some further consideration as well. First of all, it is noteworthy that the average cycle threshold $(\mathrm{Ct})$ values were high in all positive samples, indicating the abundance of low quantities of target DNA. 
This implies that a relevant proportion of samples contained target DNA amounts close to the diagnostic detection limit and thus in a range, in which PCR-amplification events become stochastic. Reduced agreement of positive results due to stochastic amplification at the diagnostic detection limit is thus an explanatory hypothesis to be considered, while unequal meta-structures due to specificity limitations or insufficient sequence conservation of the PCR targets would be an alternative explanation. The high specificity values as calculated by LCA are in contradiction to this latter alternative explanation. However, those calculations need to be interpreted with care, as the low agreement of the positive results made a calculation of the confidence intervals impossible. For the same reason, LCAestimated sensitivity values were very low for all assessed C. cayetanensis-specific real-time PCR assays. Second, the averaged Ct values in concordantly positive samples in SSU rRNA gene PCR and $18 S$ rRNA gene PCR were not lower than in discordantly positive samples, indicating that the sole effect of the target DNA amount on the agreement is probably not the only explanation for the observed high discordance rate. Third, there was moderate variance within the measured inhibition control PCR cycle threshold $(\mathrm{Ct})$ values, however, such partial inhibition should have affected all C. cayetanensis-specific real-time PCR in a similar way. However, the recorded partial inhibition phenomena suggest that the true «real-world» diagnostic detection limits were most likely higher than the recorded detection limits as measured with positive control plasmid DNA under standardized conditions. This may explain why hsp70-specific real-time PCR, which showed comparably higher detection limits even under optimized and standardized conditions, missed all samples in this assessment. The fact that low target DNA quantities were indicated by the recorded $\mathrm{Ct}$ values in the Ghanaian samples further supports this explanatory hypothesis.

Differences in the number of gene copies are another likely reason for the comparably poor sensitivity of the $h s p 70$-specific real-time PCR. As a single copy-gene, $h s p 70$ is more likely to be missed than ribosomal multi-copy genes if the target DNA concentration is close to the diagnostic detection limit. In contrast, 18 copies of the 18S rRNA gene have been described for C. cayetanensis [42], which may at least partially explain the recorded sensitivity difference.

As an interesting side finding, LCA-based diagnostic accuracy-adjusted prevalence estimation suggested a prevalence of $21.4 \%$ for $C$. cayetanensis in the assessed study population of HIVpositive Ghanaian patients. This is surprisingly high, compared to $6.0 \%$ for Cryptosporidium spp. and $3.2 \%$ for Cystoisospora belli as previously reported for this population [38,39]. While an association of increased prevalence of the coccidian parasites Cryptosporidium spp. and C. belli with HIV infection is considered as sufficiently confirmed, such an association has been reported to be much less well established for C. cayetanesis [43]. The data presented in this study are in contradiction to this doctrine and further suggest that insufficient diagnostic sensitivity might have contributed to an underestimation of $C$. cayetanensis prevalence in HIV-infected individuals in previous epidemiologic assessments [43].

The study has a number of limitations. First, the DNA samples were old and characterization by microscopy was lacking, which further reduced their value as reference materials for diagnostic accuracy assessments. However, adequate sample storage at $-80^{\circ} \mathrm{C}$ makes quantitatively relevant DNA degradation less likely and rare diagnoses of cyclosporiasis make excellently characterized $C$. cayetanasis-positive reference samples a rare resource. So, compromises regarding the choice of the samples were required and LCA helped to a least control the associated risk of bias in this test comparison without a reference standard. Second, sequencing of the PCR amplicons would have been useful to confirm or exclude specificity of individual positive real-time PCR signals. Unfortunately, funding-associated restrictions did not allow this cost-intensive confirmatory procedure, so biostatistical estimation of diagnostic accuracy was the method of choice. Third, the assessed in-house real-time PCR assays represent only a subset of described assays targeting commonly used target genes as described elsewhere [25,26,30-33]. So, they are not necessarily representative of the target genes and differing results might have resulted from a different choice of assays. Accordingly, the study just comprises a proof-of-principle assessment on 
target-gene dependence of real-time PCR based diagnosis of $C$. cayetanensis. Fourth, due to the demands by the ethical clearance for this evaluation study to be performed with anonymized diagnostic residual sample materials, no clinical data can be presented, which is an admitted deviation from the STARD (Standards for Reporting Diagnostic Accuracy) criteria [44]. Fifth, lacking availability of standardized concentrations of well-defined oocysts did not allow spiking experiments with the parasites but just the use of positive control plasmids for the assessments of the detection limits of the assays. Plasmid-based detection limits have to be interpreted with care as they do not include the releasing step of the target DNA. So, they are likely to underestimate the true detection limit in the diagnostic situation and can only be considered as an approximation.

\section{Conclusions}

In spite of the above-mentioned limitations, the study confirms previous findings on low agreement between positive results of real-time PCR assays targeting C. cayetanensis in human stool samples $[25,26]$ and suggests an association of this poor concordance with the choice of the target genes. In spite of seemingly excellent specificity in contrast to relatively poor sensitivity of the tested C. cayetanensis-specific real-time PCR assays in LCA, the question on the actual accuracy of individual positive real-time PCR signals remains unresolved. Therefore, it is recommended to confirm a positive real-time PCR result indicating the abundance of $C$. cayetanensis DNA in a stool sample by at least another diagnostic assay before a sample should be considered as a confirmed positive reference material for test evaluation and validation purposes. In addition, the results of the study call for ongoing standardization of molecular diagnostic assays targeting $C$. cayetanensis.

Author Contributions: Conceptualization, H.F. and U.L.; methodology, F.W., H.F. and A.H.; software, F.W. and A.H.; validation, F.W. and H.F.; formal analysis, A.H.; investigation, F.W. and A.H.; resources, H.F., U.L., K.A.E., T.F., F.S.S. and V.D.C.; data curation, F.W. and A.H.; writing-original draft preparation, H.F.; writing-review and editing, F.W., A.H., K.A.E., T.F., F.S.S., V.D.C., H.F. and U.L.; supervision, H.F.; project administration, H.F.; funding acquisition, H.F. and U.L. All authors have read and agreed to the published version of the manuscript.

Funding: The study was funded by grant 36K2-S-45 1922, “Evaluation and optimization of molecular diagnostic tests for tropical parasitic diseases for surveillance and risk assessment purposes in tropical deployment settings - a German-French cooperation project between the German Armed Forces Hospital Hamburg and the Military Hospital Laveran, Marseille" of the German Ministry of Defense (MoD) awarded to Hagen Frickmann. We acknowledge support by the Open Access Publication Funds of the Göttingen University.

Institutional Review Board Statement: Ethical clearance as obtained by the medical association of Hamburg, Germany, (reference number: WF-011/19, obtained on 11 March 2019) allowed anonymous use of residual sample materials for test comparison purposes without informed consent. The study was conducted according to the guidelines of the Declaration of Helsinki.

Data Availability Statement: All relevant data are provided within the manuscript. Raw data can be provided on reasonable request.

Acknowledgments: Simone Priesnitz and Annett Michel are gratefully acknowledged for excellent technical assistance.

Conflicts of Interest: The authors declare no conflict of interest. The funders had no role in the design of the study; in the collection, analyses, or interpretation of data; in the writing of the manuscript, or in the decision to publish the results. 


\section{Appendix A}

Table A1. Sequence inserts for the positive control plasmid, which was based on a pEX-A128 vector backbone.

Positive Control Insert Based on . cayetanensis Sequences according to the NCBI GenBank Accession Numbers CSU40261, AF111183,
5'-GAATTCGATTCATAGTAACCGAACGGATCGCATTTGGCTTTAGCCGGCGATAGATCATTCAAGTTTCTGACCT
ATCAGCTTTCGACGGTAGGGTATTGGCCTACCGTGGCATTGACGGGGAATTCGAGGGTCCTGTGAACTCATTG
GACTGACCAGCTGTGCTTCGCGGAGCTGGTCGGAAAGTTGCGTAAATAGAGCCCTCTAAAGGATGCAAAAGT
CGTAACACGGGAATTCCTTTCTTCCGGTAGCCTTCCGCGCTTCGCTGCGTGCGTTGGTGTTCCGGAACTTTTAC
TTTGAGAAAAATAGAGTGTTTCAAGCAGGCTTGTCGCCCTGAATACTGCAGCATGGAATAATAAGATAGGAC
CTTGGTTCTATTTGTTGGTTTCTAGGACCGAGGTAATGATTAATAGGGACAGTTGGGGCATTCGTATTTAAC
TGTCAGAGGTGAAATTCTTAGATTTGTTAAAGACGAACTACTGCGAAAGCATTTGCCAAGGATGTTTTCATTA
ATCAAGAACGACAGTAGGGGGTTTGAAGACGATTAGATACCGAATTCTGAGTGTGCATCGTGATGGGGATAG
ATTATTGCAATTATTAATCTTCAACGAGGAATGCCTAGTAGGCGCAAGTCAACAGCTTGCGCCGATTACGTCC
CTGCCCCTGTACACACCGCCCGTCGCTGCAACCGATCGGAGGGTCCTGTGAACTCATTGGACTGACCAGCTG
TGCTTCGCGGAGCTGGTCGGAAAGTTGCGTAAATAGAGCCCTCTAAAGGGAATTCCTGGAAGCGGGGGTAAG
CCACTTATTGAAGTGAACTACCAAGGTGCTACGAAGACTTTTCATCCGGAGGAAATTTCCGCCATGGTGCTGG
TGAAGATGAAGGAAATTGCCGAGTCGTTCGTTGGCAAAGAAGTTAAGGAGGCCGTTATTACAGAATTCAATT
TTGGGCGAATCACAGATTGAATCTGATGATACAGCAACATTTTTATGTGTCCGCCACCATCTGGATCAACGT
TGGTACGTTTGGAACCGCCTCGGGCGAATTC-3'

\section{References}

1. Almeria, S.; Cinar, H.N.; Dubey, J.P. Cyclospora cayetanensis and Cyclosporiasis: An Update. Microorganisms 2019, 7, 317. [CrossRef]

2. Connor, B.A. Cyclospora infection: A review. Ann. Acad. Med. Singap. 1997, 26, 632-636.

3. Helmy, M.M. Cyclospora cayetanensis: A review, focusing on some of the remaining questions about cyclosporiasis. Infect. Disord. Drug Targets 2010, 10, 368-375. [CrossRef] [PubMed]

4. Chacín-Bonilla, L. Transmission of Cyclospora cayetanensis infection: A review focusing on soil-borne cyclosporiasis. Trans. R. Soc. Trop. Med. Hyg. 2008, 102, 215-216. [CrossRef] [PubMed]

5. Li, J.; Wang, R.; Chen, Y.; Xiao, L.; Zhang, L. Cyclospora cayetanensis infection in humans: Biological characteristics, clinical features, epidemiology, detection method and treatment. Parasitology 2020, 147, 160-170. [CrossRef] [PubMed]

6. Frickmann, H.; Alker, J.; Hansen, J.; Dib, J.C.; Aristizabal, A.; Concha, G.; Schotte, U.; Kann, S. Seasonal Differences in Cyclospora cayetanensis Prevalence in Colombian Indigenous People. Microorganisms 2021, 9, 627. [CrossRef] [PubMed]

7. Shields, J.M.; Olson, B.H. Cyclospora cayetanensis: A review of an emerging parasitic coccidian. Int. J. Parasitol. 2003, 33, 371-391. [CrossRef]

8. Li, J.; Cui, Z.; Qi, M.; Zhang, L. Advances in Cyclosporiasis Diagnosis and Therapeutic Intervention. Front. Cell. Infect. Microbiol. 2020, 10, 43. [CrossRef]

9. Brown, G.H.; Rotschafer, J.C. Cyclospora: Review of an emerging parasite. Pharmacotherapy 1999, 19, 70-75. [CrossRef]

10. Mansfield, L.S.; Gajadhar, A.A. Cyclospora cayetanensis, a food- and waterborne coccidian parasite. Vet. Parasitol. 2004, 126, 73-90. [CrossRef]

11. Hadjilouka, A.; Tsaltas, D. Cyclospora Cayetanensis-Major Outbreaks from Ready to Eat Fresh Fruits and Vegetables. Foods 2020, 9, 1703. [CrossRef]

12. Ortega, Y.R.; Sanchez, R. Update on Cyclospora cayetanensis, a food-borne and waterborne parasite. Clin. Microbiol. Rev. 2010, 23, 218-234. [CrossRef] [PubMed]

13. Gascon, J.; Corachan, M.; Bombi, J.A.; Valls, M.E.; Bordes, J.M. Cyclospora in patients with traveller's diarrhea. Scand. J. Infect. Dis. 1995, 27, 511-514. [CrossRef]

14. Chacín-Bonilla, L. Epidemiology of Cyclospora cayetanensis: A review focusing in endemic areas. Acta Trop. 2010, 115, 181-193. [CrossRef]

15. Giangaspero, A.; Gasser, R.B. Human cyclosporiasis. Lancet Infect. Dis. 2019, 19, e226-e236. [CrossRef]

16. Dhanabal, J.; Selvadoss, P.P.; Muthuswamy, K. Comparative study of the prevalence of intestinal parasites in low socioeconomic areas from South chennai, India. J. Parasitol. Res. 2014, 2014, 630968. [CrossRef] [PubMed]

17. Nichols, G.L.; Freedman, J.; Pollock, K.G.; Rumble, C.; Chalmers, R.M.; Chiodini, P.; Hawkins, G.; Alexander, C.L.; Godbole, G.; Williams, C.; et al. Cyclospora infection linked to travel to Mexico, June to September 2015. Eur. Surveill. 2015, 20, 43. [CrossRef]

18. Cama, V.A.; Mathison, B.A. Infections by Intestinal Coccidia and Giardia duodenalis. Clin. Lab. Med. 2015, 35, 423-444. [CrossRef] [PubMed]

19. Shlim, D.R. Cyclospora cayetanesis. Clin. Lab. Med. 2002, 22, 927-936. [CrossRef]

20. Eberhard, M.L.; Pieniazek, N.J.; Arrowood, M.J. Laboratory diagnosis of Cyclospora infections. Arch. Pathol. Lab. Med. 1997, 121, 792-797.

21. Wurtz, R. Cyclospora: A newly identified intestinal pathogen of humans. Clin. Infect. Dis. 1994, 18, 620-623. [CrossRef]

22. Legua, P.; Seas, C. Cystoisospora and cyclospora. Curr. Opin. Infect. Dis. 2013, 26, 479-483. [CrossRef] [PubMed]

23. Quintero-Betancourt, W.; Peele, E.R.; Rose, J.B. Cryptosporidium parvum and Cyclospora cayetanensis: A review of laboratory methods for detection of these waterborne parasites. J. Microbiol. Methods 2002, 49, 209-224. [CrossRef] 
24. Meyer, J.; Roos, E.; Combescure, C.; Buchs, N.C.; Frossard, J.L.; Ris, F.; Toso, C.; Schrenzel, J. Mapping of aetiologies of gastroenteritis: A systematic review and meta-analysis of pathogens identified using a multiplex screening array. Scand. J. Gastroenterol. 2020, 55, 1405-1410. [CrossRef] [PubMed]

25. Frickmann, H.; Hoffmann, T.; Köller, T.; Hahn, A.; Podbielski, A.; Landt, O.; Loderstädt, U.; Tannich, E. Comparison of five commercial real-time PCRs for in-vitro diagnosis of Entamoeba histolytica, Giardia duodenalis, Cryptosporidium spp., Cyclospora cayetanensis, and Dientamoeba fragilis in human stool samples. Travel Med. Infect. Dis. 2021, 41, 102042. [CrossRef]

26. Köller, T.; Hahn, A.; Altangerel, E.; Verweij, J.J.; Landt, O.; Kann, S.; Dekker, D.; May, J.; Loderstädt, U.; Podbielski, A.; et al. Comparison of commercial and in-house real-time PCR platforms for 15 parasites and microsporidia in human stool samples without a gold standard. Acta Trop. 2020, 207, 105516. [CrossRef]

27. Soave, R.; Herwaldt, B.L.; Relman, D.A. Cyclospora. Infect. Dis. Clin. N. Am. 1998, 12, 1-12. [CrossRef]

28. Hahn, A.; Podbielski, A.; Meyer, T.; Zautner, A.E.; Loderstädt, U.; Schwarz, N.G.; Krüger, A.; Cadar, D.; Frickmann, H. On detection thresholds-A review on diagnostic approaches in the infectious disease laboratory and the interpretation of their results. Acta Trop. 2020, 205, 105377. [CrossRef]

29. Loderstädt, U.; Hagen, R.M.; Hahn, A.; Frickmann, H. New Developments in PCR-Based Diagnostics for Bacterial Pathogens Causing Gastrointestinal Infections-A Narrative Mini-Review on Challenges in the Tropics. Trop. Med. Infect. Dis. $2021,6,96$. [CrossRef]

30. Verweij, J.J.; Laeijendecker, D.; Brienen, E.A.; van Lieshout, L.; Polderman, A.M. Detection of Cyclospora cayetanensis in travellers returning from the tropics and subtropics using microscopy and real-time PCR. Int. J. Med. Microbiol. 2003, 293, 199-202. [CrossRef]

31. Varma, M.; Hester, J.D.; Schaefer, F.W., III; Ware, M.W.; Lindquist, H.D. Detection of Cyclospora cayetanensis using a quantitative real-time PCR assay. J. Microbiol. Methods. 2003, 53, 27-36. [CrossRef]

32. Shields, J.M.; Joo, J.; Kim, R.; Murphy, H.R. Assessment of three commercial DNA extraction kits and a laboratory-developed method for detecting Cryptosporidium and Cyclospora in raspberry wash, basil wash and pesto. J. Microbiol. Methods. 2013, 92, 51-58. [CrossRef] [PubMed]

33. Taniuchi, M.; Verweij, J.J.; Sethabutr, O.; Bodhidatta, L.; Garcia, L.; Maro, A.; Kumburu, H.; Gratz, J.; Kibiki, G.; Houpt, E.R. Multiplex polymerase chain reaction method to detect Cyclospora, Cystoisospora, and Microsporidia in stool samples. Diagn. Microbiol. Infect. Dis. 2011, 71, 386-390. [CrossRef] [PubMed]

34. Qu, Y.; Tan, M.; Kutner, M.H. Random effects models in latent class analysis for evaluating accuracy of diagnostic tests. Biometrics 1996, 52, 797-810. [CrossRef]

35. Eberhardt, K.A.; Sarfo, F.S.; Dompreh, A.; Kuffour, E.O.; Geldmacher, C.; Soltau, M.; Schachscheider, M.; Drexler, J.F.; EisHübinger, A.M.; Häussinger, D.; et al. Helicobacter pylori Coinfection Is Associated with Decreased Markers of Immune Activation in ART-Naive HIV-Positive and in HIV-Negative Individuals in Ghana. Clin. Infect. Dis. 2015, 61, 1615-1623. [CrossRef]

36. Sarfo, F.S.; Eberhardt, K.A.; Dompreh, A.; Kuffour, E.O.; Soltau, M.; Schachscheider, M.; Drexler, J.F.; Eis-Hübinger, A.M.; Häussinger, D.; Oteng-Seifah, E.E.; et al. Helicobacter pylori Infection Is Associated with Higher CD4 T Cell Counts and Lower HIV-1 Viral Loads in ART-Naïve HIV-Positive Patients in Ghana. PLoS ONE 2015, 10, e0143388. [CrossRef]

37. Tanida, K.; Hahn, A.; Eberhardt, K.A.; Tannich, E.; Landt, O.; Kann, S.; Feldt, T.; Sarfo, F.S.; Di Cristanziano, V.; Frickmann, H.; et al. Comparative Assessment of In-House Real-Time PCRs Targeting Enteric Disease-Associated Microsporidia in Human Stool Samples. Pathogens 2021, 10, 656. [CrossRef]

38. Blohm, M.; Hahn, A.; Hagen, R.M.; Eberhardt, K.A.; Rohde, H.; Leboulle, G.; Feldt, T.; Sarfo, F.S.; Di Cristanziano, V.; Frickmann, H.; et al. Comparison of Two Real-Time PCR Assays Targeting Ribosomal Sequences for the Identification of Cystoisospora belli in Human Stool Samples. Pathogens 2021, 10, 1053. [CrossRef]

39. Weinreich, F.; Hahn, A.; Hagen, R.M.; Eberhardt, K.A.; Rohde, H.; Leboulle, G.; Feldt, T.; Sarfo, F.S.; Di Cristanziano, V.; Frickmann, H.; et al. Comparison of Three Real-Time PCR Assays Targeting the SSU rRNA Gene, the COWP Gene and the DnaJ-Like Protein Gene for the Diagnosis of Cryptosporidium spp. in Stool Samples. Pathogens 2021, 10, 1113. [CrossRef]

40. Niesters, H.G.M. Quantitation of viral load using real-time amplification techniques. Methods 2001, 25, 419-429. [CrossRef]

41. Landis, J.R.; Koch, G.G. The Measurement of Observer Agreement for Categorical Data. Biometrics 1977, 33, 159-174. [CrossRef] [PubMed]

42. Murphy, H.R.; Cinar, H.N.; Gopinath, G.; Noe, K.E.; Chatman, L.D.; Miranda, N.E.; Wetherington, J.H.; Neal-McKinney, J.; Pires, G.S.; Sachs, E.; et al. Interlaboratory validation of an improved method for detection of Cyclospora cayetanensis in produce using a real-time PCR assay. Food Microbiol. 2018, 69, 170-178. [CrossRef] [PubMed]

43. Verweij, J.J.; Stensvold, C.R. Molecular testing for clinical diagnosis and epidemiological investigations of intestinal parasitic infections. Clin. Microbiol. Rev. 2014, 27, 371-418. [CrossRef] [PubMed]

44. Bossuyt, P.M.; Reitsma, J.B.; Bruns, D.E.; Gatsonis, C.A.; Glasziou, P.P.; Irwig, L.; Lijmer, J.G.; Moher, D.; Rennie, D.; De Vet, H.C.W.; et al. STARD 2015: An updated list of essential items for reporting diagnostic accuracy studies. BMJ 2015, 351, h5527. 